\title{
Fly or Cry: Is Airport Noise Costly?
}

\author{
VOLKER NITSCH
}

CESIFO WORKING PAPER NO. 2732

CATEgORy 2: Public ChOICE

JULY 2009

\footnotetext{
An electronic version of the paper may be downloaded

- from the SSRN website:

- from the RePEc website: www.SSRN.com

Www.RePEc.org

- from the CESifo website:

www.CESifo-group.org/wp
} 


\title{
Fly or Cry: Is Airport Noise Costly?
}

\begin{abstract}
Airport noise is costly. Airport location is typically associated with lower property prices. Airport expansion often sparks protests by local residents. In this paper, I provide new evidence on the costs of airport-related noise (and other disamenities of airports) for individuals. In contrast to previous work, I analyze voting results on restricting airport operations. Using data from a referendum on the closure of one of Berlin's inner-city airports, Tempelhof, I find that voting behavior is not primarily explained by exposure to airport disamenities. Rather, strong opposition to closure in the vicinity of Tempelhof indicates that adaptive preferences may be important.
\end{abstract}

JEL Code: D61, D62, H41, I18, R41.

Keywords: noise, preferences, traffic, airports.

\author{
Volker Nitsch \\ TU Darmstadt \\ International Economics \\ Marktplatz 15, Residenzschloss \\ 64283 Darmstadt \\ Germany \\ nitsch@vwl.tu-darmstadt.de
}

July 20, 2009

I thank Gabriel Ahlfeldt, Sarah Dobson, Simon Luechinger, Nicolai Wendland and seminar participants in Toronto and Zurich for helpful comments. Nicolai Wendland provided exceptional research assistance. 


\section{Introduction}

On 30 October 2008, the Berlin city government closed all operations on Tempelhof airport (IATA code THF), one of the city's three commercial airports. The closure is part of a plan to concentrate all passenger flight activities in the region at a single location, Schönefeld airport (SXF), where currently new runways and terminal buildings are being built. When the expansion of Schönefeld is completed, the new airport (called "Berlin Brandenburg International") is expected to also replace the city's current main airport, Berlin-Tegel (TXF).

The closure of Tempelhof airport was heavily disputed in public. For one thing, the airport has a long and rich history. The area has been used as an airfield since 1909 when first flight demonstrations were made by, among others, Orville Wright. With the growing emergence of air passenger traffic, Tempelhof became officially designated as an airport in 1923, making it one of the oldest commercial airports in the world. Tempelhof has also been temporarily one of the world's busiest airports. In 1926, the German national airline, Lufthansa, was founded in Tempelhof; during the 1930s, the airport handled more than 30 percent of German air passenger traffic. The importance of Tempelhof for passenger traffic declined after the end of World War II. Hub travel (and Lufthansa) relocated to West Germany; city-related air traffic increasingly shifted to Tegel which became Berlin's major airport in the mid-1970s. However, despite its decreasing role as flight destination, Tempelhof remained of large symbolic value. When, shortly after the division of Berlin among the victorious powers, Soviet authorities blocked all water- and land-borne transportation into and out of the three western-controlled sectors of Berlin, western allies supplied the population by air. Since Tempelhof was central to the Berlin Airlift operation, with more than 275,000 flights from June 1948 to May 1949, the airport became a forceful symbol for freedom for the rest of the cold war period.

Another reason for opposition to closure is the convenient geographic location of the airport. Tempelhof is situated close to the city center; the airport is well integrated into the city's public transport system. While the location in the inner-city area limits the capacity of the airport, it appears to offer good opportunities for short-distance flights or business travel.

In view of these arguments and a controversial public discussion, interest groups initiated a city-wide referendum ("Volksbegehren") on the closure of Tempelhof airport. Having a direct vote of the electorate on a specific issue (as well as the necessary preconditions for such a referendum) is defined in the constitution of Berlin. However, a ballot poll has been used for the first time in the political history of the state of Berlin. The referendum was held on 27 April 2008. In total, 881,035 votes were cast, of which the 
majority $(529,880$ or $60 \%)$ were indeed in favour of keeping the airport open. Still, the referendum failed. Since voter turnout was low (about 36\%), the votes for the initiative were only $21 \%$ of the total electorate of about 2.438 million eligible voters, while a quorum of $25 \%$ had been required.

Given that the referendum was designed as a simple yes-or-no vote on a single question, the closure of Tempelhof airport, the results of the referendum provide a natural experiment to analyze the value of intangibles. Any airport location is typically associated with benefits and costs. Amenities of airports include, among others, access to flight travel and good shopping and employment opportunities. Disamenities include, most notably, aircraft noise but also, for instance, the risk of plane crashes. Previous research (as well as frequent opposition to airport expansion) suggests that, for locations adjacent to airports, the costs outweigh the benefits. For instance, it has been widely documented that land values tend to decline as airport noise increases; see Nelson (2004) for a meta-analysis. Van Praag and Baarsma (2005) find that life satisfaction is lower for higher values of the respondent's subjective noise perception.

In this paper, I provide a novel approach to analyze the costs and benefits of airport location. The approach deviates from previous work in two important dimensions. First, I analyze direct voting behaviour. An individual's vote provides a summary record on the personal net value of airport location, taking into account all (positive and negative) aspects of nearby airport operations. For instance, to the extent that lower property prices provide full compensation for the disamenities of airport activities, individuals should be indifferent about airport closure. Also, in contrast to survey data, voting results represent a (hopefully) unbiased view. Second, I analyze evidence from airport closure. Widespread opposition to airport expansion may mainly reflect a status quo bias of local residents. Similarly, individuals who consider moving closer to the airport and thereby becoming newly exposed to airport noise may require some form of compensation for the (ex ante) anticipated disamenities. In the case of Tempelhof, in contrast, voters have been already exposed to airport operations over a considerable period of time. Voting results on closure may then even reflect adaptive preferences, with voters living close to the airport having a preference for continued operations, so that the status quo bias works in the opposite direction.

Previewing the main results, I find that in districts close to Tempelhof airport the voter's support for keeping Tempelhof airport open has been indeed particularly strong. Especially voter turnout (i.e., the extent to which voters care about the issue at poll) has been 
positively associated with airport noise levels. As a result, the costs of noise pollution from airport operations appear to be smaller than previous findings suggest.

The remainder of the paper is organized as follows. Section 2 briefly reviews the existing literature on the costs of airport noise. Section 3 provides some additional background on the Tempelhof referendum, followed by a detailed description of the data and the empirical methodology. Section 5 contains the key findings of the paper, presenting the empirical results. Section 6 briefly concludes.

\section{Literature Review}

The costs of airport noise are the subject of a large and extensive literature. Building on the insights of Pigou (1920) and Coase (1960) on the difference between social and private costs, these papers generally aim to quantify the total costs that airport location puts on society. However, since the value of intangibles, such as the pleasure of peacefulness and quietness, for individuals is often not directly observable, various indirect methods are applied.

The most prominent approach to price the amenities and disamenities of airports is to examine the effects of airport location on the value of relevant market-priced goods, such as housing and residential property. These studies typically estimate hedonic price functions in which differences in house prices are explained by various structural characteristics (such as house size) and locational attributes (e.g., crime rates). Including an additional control variable on noise levels then allows quantifying the discount that is associated with noise exposure. Standard results suggest that a one decibel increase in airport noise depreciates property values by about $0.6 \%$; Nelson (2004) provides a recent meta-analysis of 20 studies (and 33 estimates) on North American airports.

Still, despite its intuitive design, the price-based approach is not without difficulties. For one thing, the estimation of hedonic price functions may be flawed. Zoning and other forms of regulation may distort prices; also, aiming to control for all kinds of house price attributes runs the risk of omitted variable bias. More importantly, it is questionable to what extent prices do indeed measure social costs. On the one hand, house prices reflect the preferences of the marginal buyer, not society in general. On the other hand, lower house prices may provide full compensation for locational disamenities, allowing buyers, for instance, to afford larger homes. As a result, spatial sorting of home owners (depending on 
individual preferences) may ensure that the aggregate net value of intangibles is at least zero or perhaps even positive. ${ }^{1}$

An interesting approach to deal with this last issue and to identify the total effect of airport location on an individual's well-being is provided in Van Praag and Baarsma (2005). They perform an extensive survey among households living close to Amsterdam's Schiphol airport, asking, among other things, about their personal 'quality of life'. Interestingly, Van Praag and Baarsma (2005) find no association between life satisfaction and measured noise levels at the household's living place, after holding constant for other determinants of happiness. It is only when life satisfaction is compared with the respondent's perceived exposure to aircraft noise that a statistically significant negative relationship becomes detectable. This finding, however, may suffer from endogeneity. Respondents that have the subjective feeling that they are particularly exposed to noise (though, in practice, they are not) may also be more dissatisfied with their lives more generally. Another potential problem is the small sample size with a questionnaire response rate of only $17 \%$, producing in total 1400 observations.

A third approach to quantify the value of intangibles is to ask about the households' willingness to pay for environmental goods (or, alternatively, their willingness to accept compensation for a deterioration in their environment). This contingent valuation approach has been applied in the context of airport noise in Feitelson, Hurd and Mudge (1996) and Carlsson, Lampi and Martinsson (2000), among others. Although perhaps insightful, the main shortcoming of such surveys based on hypothetical questions is that respondents have little or no incentive to reveal their true valuation. Rather, they are likely to respond strategically; that is, they tend to inflate or deflate prices in order to influence the overall result according to their preferences. As a result, answers should be assessed with caution.

The natural experiment that is described and analyzed in this paper allows dealing with many of these problems in the existing literature. Direct voting on airport closure provides the ultimate feedback on an eligible voters overall assessment of the costs and benefits of airport location. Also, the number of respondents is reasonably large. Finally, the risk of strategic voting behaviour appears to be limited because the outcome of the referendum could have led to real world consequences; although the results of the referendum are de jure non-binding for the Berlin city government, it is widely agreed that a majority vote in favour of continued

\footnotetext{
${ }^{1}$ The basic structure of this argument is based on standard land rent models; see, for instance, O’Sullivan (2009, part II).
} 
operation of Tempelhof airport would have de facto exerted strong pressure on the city government to rethink their decision.

\section{The 2008 Referendum on Tempelhof Airport}

According to the Berlin constitution, binding bans and rules have to be based on laws which must have passed the Berlin parliament ("Abgeordnetenhaus"). Legislative proposals for laws typically originate from members of the parliament or the government ("Senat"). However, legislative proposals may also be initiated by individuals. More explicitly, under Articles 61-63 of the constitution, citizens may file a petition asking for a referendum on issues for which the state of Berlin has legal competence; a referendum may aim, for instance, to enact, amend or repeal a local law. ${ }^{2}$

The referendum on the closure of Tempelhof airport has been the first ballot poll on a specific issue in Berlin. There have been initiatives before, but none of these referendum demands has actually led to a poll, mainly because the initiators failed to turn in the minimum number of supporting signatures of eligible voters. The "Interest Group City Airport Tempelhof', in contrast, easily met the required minimum of 20,000 supporters; the group started its campaign on November 29, 2006 and collected 33,773 signatures by the end of March 2007. Also the next hurdle was taken by a wide margin. According to Article 63 of the Berlin constitution, for taking a referendum, $7 \%$ of the electorate (i.e., 170,385 voters) have to express their official support for the initiative by giving a signature in front of a public official (at Berlin district townhalls) within four months time. After the end of the signing period from October 15, 2007 to February 14, 2008, 204,907 Berlin citizens ( $8.4 \%$ of the eligible voters) had officially asked for a referendum which was finally held on April 27, 2008.

The broad public support for the referendum probably results from many sources, but is perhaps mainly due to the fact that there has been little obvious reason for the closure of Tempelhof airport. Tempelhof has a living history, offers a locational advantage as inner-city airport, and there is (still) no concept for the future use of this area. So, why is Tempelhof to be closed?

The decision actually reaches back to the early 1990 s when, shortly after reunification, there was broad agreement among policy-makers that air traffic in the region should be concentrated at a single airport. At this time, Berlin and the surrounding state of Brandenburg were operating three airports, mainly due to German division, with two of these airports being located in the former western part of the city of Berlin. However, especially traffic at these

\footnotetext{
${ }^{2}$ The constitution is available online at http://www.berlin.de/rbmskzl/verfassung (in German).
} 
two inner-city airports, Tegel and Tempelhof, was widely viewed as being potentially problematic for the future air traffic infrastructure in the reunified region. With the expected further increase in air travel, the inner-city location of these airports provided serious limits for a future expansion in passenger transport capacity. More importantly, flight operations at these airports were associated with elevated noise exposure and heightened risk of disaster for inner-city districts. As a result, decision was made to give up the system of airports in the region for a single airport, especially since the projected traffic volume for the region is properly handled by one large airport. After an extensive review of several possible locations for the new airport, accompanied by various forms of protest by local opponents, high-level representatives from the state and federal governments (that is, the mayor of Berlin, the governor of Brandenburg, and the federal transport minister) decided in 1996 to rebuild and expand Schönefeld airport. ${ }^{3}$ Not surprisingly, this decision generated an immense number of appeals (mostly by nearby residents); more than 4,000 persons took this issue to court. Although these appeals were generally unsuccessful, the Federal Administrative Court of Germany ("Bundesverwaltungsgericht") ruled, when deciding some of these cases, that an extension of Schönefeld airport without closing the two inner-city airports is not justified. ${ }^{4}$ Based on this ruling, the Berlin city government emphasized, besides environmental aspects, legal reasons for their insistence on the closure of Tempelhof; a departure from the original plan to close the inner-city airports would risk project (and investment) failure. A third set of arguments focuses on economic issues. With the relocation of airlines, air traffic in Tempelhof has been in decline; because of low revenues and sizable operating expenditures (which are to a large part unrelated to traffic volume), the airport has been losing money for years.

Supporters of Tempelhof airport, in contrast, highlighted the costs of airport closure. With no flight operations, jobs and revenue are lost, while there still remain sizable fixed costs (e.g., for security and maintenance). In addition, closure would imply destruction of a local advantage and the demolition of a city's landmark.

In view of these conflicting arguments, voters were asked to decide on the future of Tempelhof airport. At the end of March 2008, all eligible voters (i.e., voters eligible to vote in elections for the Berlin parliament) received an information brochure about the referendum

\footnotetext{
${ }^{3}$ For a more detailed exposition of the arguments that have led to the decision to expand Schönefeld airport, see the state development plan; the plan is available online at http://gl.berlin-brandenburg.de/imperia/md/content/bbgl/landesentwicklungsplanung/lepfs.pdf (in German).

${ }^{4} \mathrm{http}: / / w w w . b v e r w g . d e / m e d i a /$ archive/3832.pdf (in German).
} 
along with their notification. The ballot poll was finally held on April 27, 2008. In the poll, voters were confronted with a single yes-or-no question. More specifically, they were asked to express their opinion on the following statement: "The inner-city airport Tempelhof provides relief and complementary capacity to the commercial airport Berlin-Brandenburg International (BBI). The Berlin government is requested to abandon their intention of closure immediately and to lift the cancellation of the operating licence. Tempelhof must remain a commercial airport! Do you agree with this resolution? Yes/No".

Interestingly, political parties took position on this issue and gave clear recommendations for voting. The two left-wing parties in government (social democrats and former communists), not surprisingly, defended the decision to close Tempelhof airport. Also, environmentalists (greens) were in favour of closure. The two main opposition parties (christian democrats and liberals), in contrast, heavily criticized the decision of the authorities; they were, in fact, strong supporters (and to some extent even initiators) of the campaign to keep Tempelhof airport operating. In total, these five political parties accounted for about $86 \%$ of the votes during the last elections for the Berlin parliament (on September 17, 2006).

The referendum on Tempelhof airport failed. Of the 881,035 votes that were cast, a $60 \%$ majority requested continued flight operations in Tempelhof. However, the number of supportive votes $(529,880)$ fell short of the required quorum of $25 \%$ of the electorate (which would have required 609,509 yes-votes), mainly because of low voter turnout of only about $36 \%$. As a result, air traffic at Tempelhof airport was suspended, as planned by authorities, on October 30, 2008. The official licence expired in mid-December 2008.

\section{Methodology and Data}

Individual preferences for airport location may be affected by various motives. A first set of motives focuses on intangibles. The most prominent intangible of airport operations is aircraft noise; in the vicinity of airports, people are exposed to elevated sound levels which may cause negative health effects such as stress, annoyance, hearing impairment and sleep disturbance. Other potential disamenities of flight operations include increased pollution, greater insecurity because of the higher risk of plane crashes during take-off and landing, and extensive airport-related commuter traffic.

Another set of motives is related to pecuniary economic aspects. For instance, as already well documented, residential property prices are often lower in the vicinity of airports. As a result, property owners tend to lose from (and therefore typically oppose) airport location/expansion, while (noise-resistant) renters of homes may benefit from lower rent 
levels. Moreover, since airports provide access to (travel) services, customers and suppliers of these services have an incentive to locate close to the airport to minimize commuting costs.

Finally, it has recently been argued that preferences can be adaptive to existing institutions; see Alesina and Fuchs-Schündeln (2007). Therefore, Tempelhof residents (who have been exposed to airport noise for years) have perhaps become accustomed to nearby flight activities and thereby rather voted for continued operations.

In the following, I analyze empirically the relative importance of these preferences for airport location by examining voting behavior. The referendum on Tempelhof airport provides, for the first time, evidence on people's overall assessment of airports; exploring local differences in voting results then allows identifying factors of importance in individual cost-benefit analyses of airport location.

Specifically, I argue that, to the extent airport noise is costly, in districts close to Tempelhof airport (or, more precisely, given tightly defined flight corridors for take-off and landing, in districts that are particularly exposed to aircraft noise), the preference for closure of Tempelhof airport should have been particularly strong. Put differently, noise exposure and support for further operation should be negatively correlated (hypothesis \#1). Alternatively, if local residents are compensated for the disamenities of airport activities (e.g., by lower rents or airport amenities), voters are likely to be indifferent about airport closure. There should be no measurable association between exposure to airport noise and voting behavior (hypothesis \#2). Finally, if voting behavior is dominated by adaptive preferences, voters in the vicinity of the airport should have been particularly in favor of continued operations. As a result, I would expect to find a positive association between a district's exposure to airport noise and the local voters' support for the initiative to keep Tempelhof airport open (hypothesis \#3).

When reviewing the potential determinants of voting behavior on Tempelhof airport in detail, three additional considerations appear to be of relevance. First, voting results are unlikely to be affected by strategic behaviour of voters for personal purposes. For instance, individual pecuniary interests (such as the fear of increases in local rents after airport closure) have been probably of minor importance for voting preferences. Given that the future development of the airfield in Tempelhof is not yet decided, the impact of airport closure on local property prices is unclear. ${ }^{5}$ Also, the small scale of regular flight operations at

\footnotetext{
${ }^{5}$ Using a hedonic price model, Ahlfeldt and Maennig (2008) estimate that land values for areas exposed to noise pollution of Tempelhof airport sell at a discount of approximately 5$9 \%$ within a distance of 5000 meters along the air corridor. However, this result (as well as Ahlfeldt and Maennig's finding of no land value discount for the much more busy Tegel
} 
Tempelhof airport clearly limits the attractiveness of this airport for frequent travellers. In 2007, seven airlines offered flight services from Tempelhof to 54 destinations in five countries (with Brussels and Copenhagen being the main destinations). Tegel airport, in contrast, is served by 57 airlines, offering connections to 113 destinations in 41 countries. Second, voting behavior on Tempelhof may exhibit a clear east-west pattern. Since Tempelhof airport has a strong symbolic value for residents in the western part of the city, voters in this part of the city may have a particularly strong preference for ongoing operations (despite suffering most strongly from airport disamenities). Differences in voting behavior between the former eastern and western parts of the city could then be just another illustration of adaptive preferences. Third, voting patterns on Tempelhof may have been affected by political preferences. Political parties gave clear recommendations on voting. In fact, the referendum campaign on Tempelhof airport has been, at least in part, an initiative by major opposition parties to generate a vote of no confidence for the ruling coalition in the Berlin city government. As a result, some voters perhaps went to poll for political reasons even though they have no position on the referendum issue.

In practice, voters may have expressed their preferences about Tempelhof airport in the referendum in two separate ways. On the one hand, voters may have answered the question about flight operations in Tempelhof directly by participating in the ballot poll. On the other hand, people may have shown disinterest in this issue by ignoring the poll, thereby effectively weakening the campaign to keep Tempelhof open. In the empirical analysis, I use the number of valid yes-votes as a share of the eligible population as measure of support for Tempelhof airport.

The referendum on Tempelhof airport has been a secret poll so that individual voting behavior is not known. However, voting results are available for a spatially finely disaggregated grid of local polling places in Berlin. In total, there have been 1,201 local polling places where the referendum was taken; these places (mostly located in public schools) covered areas of different geographic size, but were set up for on average about 2,000 eligible voters. Figure 1 provides a map of these polling districts along with the percentage of yesvotes.

A potential problem is that a sizable fraction of the electorate voted by mail; about $26 \%$ of the votes $(230,571)$ were not taken at polling places but sent by mail so that the resident location area of the voter cannot be determined exactly. Fortunately, however, voting

airport) was met with great skepticism by practitioners; see Kurpjuweit and Stollowsky (2008). 
patterns do not differ by the mode of vote taking. Figure 2 graphs the percentage of yes-votes for ballot votes and mailed votes by city district; there are 12 city districts in Berlin. With a correlation of 0.99 , the differences in voting patterns appear negligible.

In the empirical analysis, I examine differences in voting results on airport closure across local polling places. The key explanatory variable of interest is local exposure to airport noise from Tempelhof airport. If airport noise (and any other form of flight-related disamenities) is of major importance for the location decision of Berlin citizens, residents located close to the airport should have a particular interest in closure of Tempelhof; the disappearance of local disamenities associated with flight activities would then imply, for these residents, a sizable gain (e.g., in their quality-of-living), without any obvious losses.

In addition, I include a number of other explanatory variables. The benchmark model includes, for instance, a binary dummy variable that takes the value of one if the polling place is located in the former western part of Berlin; this variable allows capturing the symbolic value of the airport (as a symbol for freedom). Measures of political orientation control for party preferences. In sum, I run OLS regressions of the form:

$$
\text { Vote }_{\mathrm{i}}=\alpha+\beta \mathrm{THF}_{\mathrm{i}}+\gamma \mathrm{X}_{\mathrm{i}}+\varepsilon_{\mathrm{i}}
$$

where Vote $_{i}$ is a measure of the referendum outcome at polling place $\mathrm{i}, \mathrm{THF}_{\mathrm{i}}$ is the extent of disamenity from Tempelhof airport at $\mathrm{i}, \mathrm{X}$ is a vector of other control variables, and $\varepsilon$ is a (hopefully) well-behaved residual.

Data on voting results by polling place are obtained from the state statistical office of Berlin-Brandenburg. ${ }^{6}$ The data set contains, for each polling place, information on the number of eligible voters, the number of votes cast and the number of yes- (and no-)votes. Based on this data, I compute the fraction of the electorate who voted "yes", the fraction of voters who voted "yes" and the fraction of voters in the electorate (i.e., voter turnout) at each polling place; these variables measure local preferences for continued airport operations in Tempelhof, used as dependent variable in the analysis $\left(V t_{i}\right)$. The same source is used for information on

\footnotetext{
${ }^{6}$ I am grateful to Geert Baasen from the bureau of the election supervisor at the state statistical office of Berlin-Brandenburg for the provision of the data. Other useful information on the Tempelhof referendum (including a copy of the ballot paper) is available online at http://www.wahlen-berlin.de/wahlen/framesets/ve-2008.htm.
} 
local political preferences; I use the results from elections for the Berlin parliament on September $17,2006 .^{7}$

Local disamenities of Tempelhof airport $\left(\mathrm{THF}_{\mathrm{i}}\right)$ are proxied by airport noise levels. In principle, very detailed measures of airport-related noise are available. The Berlin airport authority provides, for instance, daily information on the frequency distribution of maximum noise levels and the equivalent long-term noise level measured at individual noise measurement stations around the airports; there are six of these stations in the case of Tempelhof. ${ }^{8}$ In practice, however, these detailed statistics are, for my purposes, of little help. The number of locations for which flight-related noise levels are available is small. Also, the measurement stations are located very closely to the airport so that effectively only a small area of the city of Berlin is covered. Most notably, however, the equivalent long-term noise levels at the measurement stations do not deviate strongly from measured noise pollution at other locations. In fact, it is required by law to officially determine noise protection zones in which land use activities are restricted. For Tempelhof, the noise protection zone which covers areas exposed to an equivalent long-term sound pressure level of more than $67 \mathrm{~dB}(\mathrm{~A})$ barely exceeds airport territory. ${ }^{9}$

In the implementation, therefore, I begin by determining average noise levels in individual polling districts. For this purpose, I use data from the 2008 edition of the Berlin Digital Environmental Atlas provided by the Senate Department for Urban Development, available online at http://www.stadtentwicklung.berlin.de/umwelt/umweltatlas/edinh_07.htm. This atlas offers strategic noise maps which cover noise levels in the city of Berlin at a very detailed $5 \times 5$ meter grid. After having been digitally processed within a standard GIS environment, the data are matched with information on the area and location of the polling districts; the geographic division of constituencies in the city of Berlin is based on a georeferenced GIS map which is taken from the Urban and Environmental Information System of the Senate Department for Urban Development and also available online at http://www.stadtentwicklung.berlin.de/geoinformation/index.shtml. More specifically, pixels from noise maps are assigned to corresponding polling districts, and a representative (districtwide) mean of the noise level is computed. In a very conservative approach, then, it is

\footnotetext{
${ }^{7}$ For some polling places, there has been a minor redesign in the geographic area that is covered. As a result, the number of polling places with usable data falls to 1,197.

${ }^{8}$ The data are available online at http://www.berlinairport.de/EN/GruenerFlughafen/Fluglaerm/Fluglaerm.html.

${ }^{9}$ Stronger restrictions apply to an inner zone with noise exposure to more than $75 \mathrm{~dB}(\mathrm{~A})$; see http://www.stadtentwicklung.berlin.de/umwelt/umweltatlas/e_text/k706.pdf (in German). This zone is located completely on the property of Tempelhof airport.
} 
assumed that all measured noise pollution in the immediate vicinity of Tempelhof airport is due to flight activities.

As an alternative measure, I use the plain direct-line distance to Tempelhof airport as a proxy for flight-related disamenities. In order to make sure that the estimation results are not affected by the exact specification of the distance measure, I experiment with various distance measures: distance to airport, circles of varying distance around the airport, and distance to the boundary of the noise protection zone around Tempelhof airport. Descriptive statistics for the variables used in the empirical analysis are tabulated in the appendix.

\section{Empirical Results}

Table 1 presents the benchmark results. I begin by examining differences in voting patterns on Tempelhof airport as measured by the percentage of yes-voters in the total electorate; this variable is the most comprehensive measure of referendum outcome, combining the two prerequisites for a success of the initiative to keep the airport open: a majority of yes-votes in the referendum and a quorum of $25 \%$ of the electorate. The main variable of interest is the level of disamenities from flight activities at Tempelhof airport. In the baseline specification, I use location of a polling district in the noise protection zone of Tempelhof airport as a proxy for flight-related noise pollution. The residential population of these (two) polling districts is particularly exposed to aircraft noise and, therefore, can be expected to benefit most strongly from closure of the airport. As shown in column 1, however, the estimated coefficient on this dummy variable is positive and, with a t-statistic of 1.7 , weakly statistically significant. Taken literally, the coefficient estimate indicates that voters in the immediate vicinity of the flight corridors of Tempelhof airport opted, if anything, primarily in favor of continued airport operations, by a margin of about $4.5 \%$ of the electorate. While moderate noise disturbance around Tempelhof airport (e.g., due to limited flight activities, departure and landing of only small airplanes, soundproof homes) may be part of the explanation, this finding is a strong indication of adaptive preferences. People who have been exposed to the amenities and disamenities of nearby airport operations appear to have a distinct preference for the status quo.

In the regressions, I control for a set of other potential determinants of the referendum vote by polling place. Most notably, I include a dummy variable for location of the polling district in the former eastern part of Berlin. The estimated coefficient on this variable is significantly negative, indicating a much greater preference for closure of the inner-city airport in areas without any historic relationship to the airport. This finding provides 
additional support for the hypothesis of adaptive preferences, along the lines of Alesina and Fuchs-Schündeln (2007). Plausible coefficient estimates are also obtained for political preferences. Voting results are strongly correlated with preferences for political parties during the last (2006) elections: A larger share of votes for the two right-wing opposition parties in the Berlin parliament, christian democrats and liberals, is associated with greater support for Tempelhof; a strong position of the former communist party is associated with a larger preference for closure. In sum, it is reassuring to note that the estimation model yields strong and convincing results. The regression specification fits the data remarkably well, explaining about $83 \%$ of the variation in the referendum outcome by polling district.

Next, I gradually extend the area assumed to be affected by flight operations at Tempelhof airport. Results are tabulated in columns 2 to 4 . In column 2, I consider all polling districts located less than 500 meters from the noise protection zone. Specifically, I assume that the measured sound pressure levels in these (11) districts are entirely due to flight activities. Accordingly, noise pollution in other polling districts is set to be zero. The results strongly confirm the baseline estimates. The estimated coefficient on the disamenity measure is again positive and, in this specification, also highly significant statistically. ${ }^{10}$ Column 3 uses location of a polling district within a circle of increasing distance to Tempelhof airport as a proxy for airport-related disamenities. I consider circles of up to 2 kilometers, 2 to 4 kilometers, and 4 to 6 kilometers from Tempelhof; polling districts with greater distance to Tempelhof airport might already be located closer to another Berlin airport. Again, the estimation results forcefully suggest that support for Tempelhof airport has been unusually strong in the immediate vicinity of the airport. Similar results are obtained for a measure of continuous distance from Tempelhof airport (that also considers differences in voting results for polling districts not directly affected by airport operations). As shown in column 4, distance is negatively associated with the referendum vote for Tempelhof.

The last column on the extreme right of Table 1 takes a broader approach and examines whether differences in the referendum vote across polling districts are partly explained by the mean sound pressure level in a voter's residential area. Interestingly, the estimated coefficient on the noise measure is significantly negative. Hence, the regression yields essentially conventional results: Greater noise exposure reduces the support for future operation of a potential major source of noise. Interestingly, voters in noisier areas oppose

\footnotetext{
${ }^{10}$ Qualitatively similar results are obtained when noise levels are replaced by a plain binary dummy variable (similar to the approach in the baseline specification). Compared with the results in column 1, the estimated coefficient falls in magnitude to 2.7 , but increases in its level of statistical significance. Detailed results are not reported.
} 
further flight operations at Tempelhof airport, even though their personal benefit from a discontinuation of noise emission from this particular source of noise appears to be negligible (and may be even negative due to a relocation of flight activities to other Berlin airports). This finding is roughly in line with van Praag and Baarsma's (2005) observation that it is primarily a person's subjective exposure to noise that matters for the assessment of noise disamenities. The estimation result that there is generally a negative association between noise exposure and referendum vote further highlights the role of adaptive preferences for voting patterns in the vicinity of Tempelhof airport.

To ensure robustness of the results, I perform extensive sensitivity checks. In a first exercise, I experiment with various other measures of referendum outcome as dependent variable. In column 1 of Table 2, I explore voting patterns among active voters. This column tabulates results for the specification of the baseline model that appears to capture voting patterns around Tempelhof airport in the most appropriate way (analogous to column 3 of Table 1), when the percentage of yes-votes to the total number of votes cast (instead of the maximum number of potential votes) is used as dependent variable. For this modification, the estimation results are slightly weaker. The estimated coefficients on the main variables of interest, moderate distance of varying degree from Tempelhof airport, fall in magnitude and sometimes even lose statistical significance. Still, support for Tempelhof remains, if anything, above average in polling districts close to Tempelhof airport, after holding constant for other factors. Focusing on active voters strengthens results on political preferences, with negative coefficients on the vote share of parties in government (social democrats, former communists) and the environmentalists. The adjusted $\mathrm{R}^{2}$ increases to 0.88 . Column 3 shows that greater support for the referendum in the vicinity of the airport mainly stems from higher voter participation rates. Voter turnout has been higher by up to 5 percentage points in areas close to the airport, other things equal. In contrast, judged by voter interest and participation, there is little difference in voting behavior between the eastern and western parts of the city.

The remaining three columns of Table 2 present analogous estimates when referendum votes are transformed into binary variables that take the value of one if the requirements for a successful referendum are met. In column 4 , the dependent variable is one if the number of yes-votes in a polling district represents the majority of votes and a quorum of $25 \%$ of the electorate; there are 250 polling districts in which these conditions are met. The two columns on the right of Table 2 report corresponding figures for the two conditions separately. ${ }^{11}$ The

\footnotetext{
${ }^{11}$ In polling districts where yes-votes represent at least $25 \%$ of the electorate, the majority of voters always opted for continued airport operations.
} 
main findings remain basically unchanged. Opposition to closure is disproportionately large in the surroundings of Tempelhof airport, mainly due to greater voter turnout.

Table 3 examines the sensitivity of the results with respect to the inclusion of additional control variables. I add to the default specification: a) the mean noise level; b) the $\log$ distance to Tempelhof airport; c) the full set of election results (covering 28 political parties and groups); d) the log number of eligible voters; and e) the log area of the polling district. The main findings were robust to these perturbations. Voters in the immediate vicinity of Tempelhof airport expressed the strongest support for the initiative to keep the airport open.

In sum, there is consistent evidence that voting behavior on the closure of Tempelhof airport is not dominated by exposure to disamenities from airport operations. On the contrary, voters living in the surroundings of the airport even exhibit a clear pattern in favor of continued operations. As a result, airport noise appears to be less costly than previous findings suggest.

\section{Conclusions}

Traffic noise is annoying. In this paper, I examine new evidence on the costs of airport-related noise (and other disamenities of airports) for individuals. In contrast to previous work which mainly focuses on property prices to document the costs of airport noise, I analyze voting results from a recent city-wide ballot poll on airport closure; direct voting should provide useful insights on the overall assessment of the costs and benefits of an airport by residents. Also, respondents participating in this poll have already experienced the disamenities of airport operations while earlier evidence seems to reflect mainly expectations of annoyance formed ex ante before actual exposure.

Using data from a referendum on the closure of one of Berlin's inner-city airports, Tempelhof, I find a number of interesting results. First, voting behavior is not primarily explained by exposure to airport disamenities. Noise pollution is not the main feature of airport operations that necessarily determines individual perceptions about flight activities. Second, strong opposition to closure in the vicinity of Tempelhof indicates the existence of status quo bias. The dominance of this effect provides another forceful illustration of the role of adaptive preferences. Third, this finding is reinforced by the empirical observation of a sizable difference in voting patterns between the eastern and the western part of the city. Holding other things (such as political preferences) constant, voters in the former West Berlin 
display a significantly greater preference for continued operations, despite suffering most from airport noise pollution.

In summary, I provide evidence that individual's may become accustomed with disamenities and adjust their preferences accordingly. 
References:

Ahlfeldt, Gabriel and Wolfgang Maennig. 2008. "Assessing External Effects of City Airports: Land Values in Berlin," University of Hamburg.

Alesina, Alberto and Nicola Fuchs-Schündeln. 2007. "Good Bye Lenin (or Not?): The Effect of Communism on People's Preferences," American Economic Review. 97 (September): 1507-1528.

Carlsson, Fredrik, Elina Lampi and Peter Martinsson. 2000. "The Marginal Values of Noise Disturbance from Air Traffic: Does the Time of the Day Matter?" Transportation Research (Part D). 9 (September): 373-385.

Coase, Ronald. 1960. "The Problem of Social Cost," Journal of Law and Economics. 3 (October): 1-44.

Feitelson, Eran I., Robert E. Hurd and Richard R. Mudge. (1996). “The Impact of Airport Noise on Willingness to Pay for Residences," Transportation Research (Part D). 1 (September): 1-14.

Jenks, George F. 1977. “Optimal Data Classification for Choropleth Maps,” Occasional Paper No. 2. University of Kansas. Lawrence, Kansas.

Kurpjuweit, Klaus and Christoph Stollowsky. 2008. "Tempelhof ist in - nach dem Aus," Tagesspiegel. February 24.

Luechinger, Simon. 2009. "Valuing Air Quality Using the Life Satisfaction Approach," Economic Journal. 119 (March): 482-515.

Nelson, Jon P. 2004. "Meta-Analysis of Airport Noise and Hedonic Property Values:

Problems and Prospects," Journal of Transport Economics and Policy. 38 (January): 1-28.

O’Sullivan, Arthur. 2009. Urban Economics. Seventh Edition. New York: McGraw-Hill/Irwin.

Pigou, Arthur C. 1920. The Economics of Welfare. London: Macmillan.

Redding, Stephen J., Daniel M. Sturm and Nikolaus Wolf. 2007. "History and Industry Location: Evidence from German Airports,” CEPR Discussion Paper \# 6345.

van Praag, Bernard M. S. and Barbara E. Baarsma. 2005. "Using Happiness Surveys to Value Intangibles: The Case of Airport Noise," Economic Journal. 115 (January): 224-246. 
Table 1: Benchmark results

\begin{tabular}{|c|c|c|c|c|c|}
\hline $\begin{array}{l}\text { Noise Protection } \\
\text { Zone }\end{array}$ & $\begin{array}{r}4.477 \# \\
(2.658) \\
\end{array}$ & & & & \\
\hline $\begin{array}{l}\text { Noise }(<500 m \text { from } \\
\text { THF) }\end{array}$ & & $\begin{array}{l}0.046^{*} \\
(0.020)\end{array}$ & & & \\
\hline 0-2km from THF & & & $\begin{array}{l}2.525 * * \\
(0.891)\end{array}$ & & \\
\hline $2-4 \mathrm{~km}$ from $\mathrm{THF}$ & & & $\begin{array}{l}1.926^{* *} \\
(0.451)\end{array}$ & & \\
\hline 4-6km from THF & & & $\begin{array}{r}0.795^{*} \\
(0.335) \\
\end{array}$ & & \\
\hline Distance from $\mathrm{THF}$ & & & & $\begin{array}{l}-1.236^{* *} \\
(0.226) \\
\end{array}$ & \\
\hline Noise & & & & & $\begin{array}{l}-0.114^{* *} \\
(0.021)\end{array}$ \\
\hline East & $\begin{array}{l}-1.825 * * \\
(0.420)\end{array}$ & $\begin{array}{l}-1.776^{* *} \\
(0.421)\end{array}$ & $\begin{array}{l}-1.316^{* *} \\
(0.431)\end{array}$ & $\begin{array}{l}-1.417 * * \\
(0.423)\end{array}$ & $\begin{array}{l}-1.892^{* *} \\
(0.415)\end{array}$ \\
\hline SPD & $\begin{array}{l}2.451 \\
(4.159)\end{array}$ & $\begin{array}{l}2.692 \\
(4.157)\end{array}$ & $\begin{array}{l}5.561 \\
(4.278) \\
\end{array}$ & $\begin{array}{l}2.020 \\
(4.106)\end{array}$ & $\begin{array}{c}4.843 \\
(4.140)\end{array}$ \\
\hline CDU & $\begin{array}{l}57.950 * * \\
(3.900)\end{array}$ & $\begin{array}{l}58.241^{* *} \\
(3.901)\end{array}$ & $\begin{array}{l}60.243 * * \\
(3.954)\end{array}$ & $\begin{array}{l}59.083 * * \\
(3.860)\end{array}$ & $\begin{array}{l}55.176^{* *} \\
(3.878)\end{array}$ \\
\hline Linke & $\begin{array}{l}-9.686^{* *} \\
(3.575)\end{array}$ & $\begin{array}{l}-9.450 * * \\
(3.574) \\
\end{array}$ & $\begin{array}{l}-7.620^{*} \\
(3.627) \\
\end{array}$ & $\begin{array}{l}-9.777^{* *} \\
(3.532)\end{array}$ & $\begin{array}{c}-10.707 * * \\
(3.536) \\
\end{array}$ \\
\hline FDP & $\begin{array}{l}29.837 * * \\
(5.461)\end{array}$ & $\begin{array}{l}30.208^{* *} \\
(5.460)\end{array}$ & $\begin{array}{l}37.196^{* *} \\
(5.196)\end{array}$ & $\begin{array}{l}33.215^{* *} \\
(5.439)\end{array}$ & $\begin{array}{l}30.822^{* *} \\
(5.403)\end{array}$ \\
\hline Grüne & $\begin{array}{l}3.595 \\
(2.808) \\
\end{array}$ & $\begin{array}{l}3.807 \\
(2.808) \\
\end{array}$ & $\begin{array}{c}3.231 \\
(2.829) \\
\end{array}$ & $\begin{array}{c}0.791 \\
(2.814) \\
\end{array}$ & $\begin{array}{c}1.752 \\
(2.791) \\
\end{array}$ \\
\hline Adj. R2 & 0.83 & 0.83 & 0.83 & 0.83 & 0.83 \\
\hline
\end{tabular}

Notes: OLS estimation. Dependent variable: Percentage share of yes-votes in electorate. Standard errors are reported in parentheses. **, * and \# denote significant at the 1, 5 and 10 percent level, respectively. The number of observations is 1,197 . 
Table 2: Other measures of referendum outcome

\begin{tabular}{|c|c|c|c|c|c|}
\hline $\begin{array}{r}\text { Dependent } \\
\text { variable: }\end{array}$ & $\begin{array}{l}\text { Percentage } \\
\text { share of } \\
\text { yes-votes in } \\
\text { total votes }\end{array}$ & $\begin{array}{l}\text { Percentage } \\
\text { rate of } \\
\text { voter } \\
\text { partici- } \\
\text { pation }\end{array}$ & $\begin{array}{l}\text { Majority of } \\
\text { votes = yes } \\
\& \text { yes-votes } \\
\geq 25 \% \text { of } \\
\text { electorate }\end{array}$ & $\begin{array}{l}\text { Majority of } \\
\text { votes = yes }\end{array}$ & $\begin{array}{l}\text { Yes-votes } \geq \\
25 \% \text { of } \\
\text { electorate }\end{array}$ \\
\hline 0-2km from $\mathrm{THF}$ & $\begin{array}{c}0.908 \\
(1.723)\end{array}$ & $\begin{array}{l}4.941^{* *} \\
(1.118)\end{array}$ & $\begin{array}{c}1.588 \# \\
(0.915) \\
\end{array}$ & $\begin{array}{c}0.653 \\
(0.982)\end{array}$ & $\begin{array}{c}1.588 \# \\
(0.915) \\
\end{array}$ \\
\hline $2-4 \mathrm{~km}$ from $\mathrm{THF}$ & $\begin{array}{c}1.715^{*} \\
(0.872) \\
\end{array}$ & $\begin{array}{l}2.881 * * \\
(0.566)\end{array}$ & $\begin{array}{l}1.654 * * \\
(0.429)\end{array}$ & $\begin{array}{l}-0.409 \\
(0.630) \\
\end{array}$ & $\begin{array}{l}1.654 * * \\
(0.429)\end{array}$ \\
\hline 4-6km from $\mathrm{THF}$ & $\begin{array}{c}0.288 \\
(0.647)\end{array}$ & $\begin{array}{l}1.269^{* *} \\
(0.420)\end{array}$ & $\begin{array}{l}0.877 * * \\
(0.331)\end{array}$ & $\begin{array}{l}-0.842 \\
(0.535)\end{array}$ & $\begin{array}{l}0.877 * * \\
(0.331)\end{array}$ \\
\hline East & $\begin{array}{l}-5.871 * * \\
(0.834)\end{array}$ & $\begin{array}{c}0.500 \\
(0.541) \\
\end{array}$ & $\begin{array}{c}0.464 \\
(0.504) \\
\end{array}$ & $\begin{array}{l}-1.772 * * \\
(0.642)\end{array}$ & $\begin{array}{c}0.464 \\
(0.504) \\
\end{array}$ \\
\hline SPD & $\begin{array}{l}-5.952 \\
(8.274)\end{array}$ & $\begin{array}{c}29.558 * * \\
(5.369)\end{array}$ & $\begin{array}{l}-3.208 \\
(5.087)\end{array}$ & $\begin{array}{c}6.956 \\
(6.125) \\
\end{array}$ & $\begin{array}{l}-3.208 \\
(5.087)\end{array}$ \\
\hline CDU & $\begin{array}{c}22.634 * * \\
(7.646)\end{array}$ & $\begin{array}{l}88.765^{* *} \\
(4.962)\end{array}$ & $\begin{array}{l}32.942 * * \\
(4.527)\end{array}$ & $\begin{array}{c}10.144 \# \\
(6.099) \\
\end{array}$ & $\begin{array}{l}32.942 * * \\
(4.527)\end{array}$ \\
\hline Linke & $\begin{array}{c}-124.365^{* *} \\
(7.015) \\
\end{array}$ & $\begin{array}{c}37.286^{* *} \\
(4.552)\end{array}$ & $\begin{array}{c}5.127 \\
(4.968) \\
\end{array}$ & $\begin{array}{c}-28.915^{* *} \\
(5.884)\end{array}$ & $\begin{array}{c}5.127 \\
(4.968) \\
\end{array}$ \\
\hline FDP & $\begin{array}{l}26.704 * * \\
(10.967)\end{array}$ & $\begin{array}{l}47.642^{* *} \\
(7.116)\end{array}$ & $\begin{array}{l}20.539 * * \\
(5.870)\end{array}$ & $\begin{array}{c}14.596 \\
(10.948)\end{array}$ & $\begin{array}{l}20.539 * * \\
(5.870)\end{array}$ \\
\hline Grüne & $\begin{array}{c}-91.122 * * \\
(5.472)\end{array}$ & $\begin{array}{c}48.637 * * \\
(3.551) \\
\end{array}$ & $\begin{array}{c}2.454 \\
(3.185) \\
\end{array}$ & $\begin{array}{c}-18.527 * * \\
(4.823)\end{array}$ & $\begin{array}{c}2.454 \\
(3.185) \\
\end{array}$ \\
\hline Estimation method & OLS & OLS & Logit & Logit & Logit \\
\hline Adj. R2 & 0.88 & 0.64 & & & \\
\hline Pseudo R2 & & & 0.56 & 0.82 & 0.56 \\
\hline
\end{tabular}

Notes: Standard errors are reported in parentheses. $* *, *$ and \# denote significant at the 1, 5 and 10 percent level, respectively. The number of observations is 1,197 . 
Table 3: Additional controls

\begin{tabular}{|c|c|c|c|c|c|}
\hline 0-2km from THF & $\begin{array}{l}2.357 * * \\
(0.882)\end{array}$ & $\begin{array}{c}0.660 \\
(1.168)\end{array}$ & $\begin{array}{l}2.680 * * \\
(0.878)\end{array}$ & $\begin{array}{l}2.624 * * \\
(0.889)\end{array}$ & $\begin{array}{l}2.516^{* *} \\
(0.896)\end{array}$ \\
\hline 2-4km from THF & $\begin{array}{l}1.739 * * \\
(0.448)\end{array}$ & $\begin{array}{c}0.809 \\
(0.639)\end{array}$ & $\begin{array}{l}2.389 * * \\
(0.464)\end{array}$ & $\begin{array}{l}1.971^{* *} \\
(0.450)\end{array}$ & $\begin{array}{l}1.922^{* * *} \\
(0.453)\end{array}$ \\
\hline 4-6km from THF & $\begin{array}{c}0.825^{*} \\
(0.331)\end{array}$ & $\begin{array}{c}0.156 \\
(0.423)\end{array}$ & $\begin{array}{c}0.800^{*} \\
(0.333)\end{array}$ & $\begin{array}{c}0.847^{*} \\
(0.334)\end{array}$ & $\begin{array}{c}0.797^{*} \\
(0.335)\end{array}$ \\
\hline Noise & $\begin{array}{l}-0.107 * * \\
(0.021)\end{array}$ & & & & \\
\hline Distance from THF & & $\begin{array}{l}-0.939 * \\
(0.381)\end{array}$ & & & \\
\hline Electorate & & & & $\begin{array}{l}-0.665^{* *} \\
(0.239)\end{array}$ & \\
\hline Area & & & & & $\begin{array}{c}0.011 \\
(0.120)\end{array}$ \\
\hline East & $\begin{array}{l}-1.382 * * \\
(0.427)\end{array}$ & $\begin{array}{l}-1.324 * * \\
(0.430)\end{array}$ & $\begin{array}{l}-1.615^{* *} \\
(0.442)\end{array}$ & $\begin{array}{l}-1.337 * * \\
(0.430)\end{array}$ & $\begin{array}{l}-1.324^{* *} \\
(0.439)\end{array}$ \\
\hline SPD & $\begin{array}{c}7.661 \# \\
(4.254)\end{array}$ & $\begin{array}{c}3.686 \\
(4.337)\end{array}$ & $\begin{array}{c}177.535 \\
(131.172)\end{array}$ & $\begin{array}{c}4.539 \\
(4.282)\end{array}$ & $\begin{array}{c}5.576 \\
(4.283)\end{array}$ \\
\hline CDU & $\begin{array}{c}57.607 * * \\
(3.946)\end{array}$ & $\begin{array}{c}59.875^{* *} \\
(3.948)\end{array}$ & $\begin{array}{c}230.020 \# \\
(131.080)\end{array}$ & $\begin{array}{c}59.837 * * \\
(3.945)\end{array}$ & $\begin{array}{c}60.187 * * \\
(4.003)\end{array}$ \\
\hline Linke & $\begin{array}{l}-8.705^{*} \\
(3.595)\end{array}$ & $\begin{array}{l}-8.731^{*} \\
(3.647)\end{array}$ & $\begin{array}{c}165.768 \\
(131.210)\end{array}$ & $\begin{array}{l}-7.516^{*} \\
(3.617)\end{array}$ & $\begin{array}{l}-7.650^{*} \\
(3.643)\end{array}$ \\
\hline FDP & $\begin{array}{c}37.742^{* * *} \\
(5.612)\end{array}$ & $\begin{array}{c}35.439^{* *} \\
(5.703)\end{array}$ & $\begin{array}{c}208.239 \\
(131.256)\end{array}$ & $\begin{array}{l}36.773^{* *} \\
(5.656)\end{array}$ & $\begin{array}{l}37.105^{* *} \\
(5.758)\end{array}$ \\
\hline Grüne & $\begin{array}{c}1.578 \\
(2.819)\end{array}$ & $\begin{array}{c}1.487 \\
(2.911)\end{array}$ & $\begin{array}{c}179.380 \\
(131.081)\end{array}$ & $\begin{array}{c}2.899 \\
(2.824)\end{array}$ & $\begin{array}{c}3.236 \\
(2.831)\end{array}$ \\
\hline 23 other parties & No & No & Yes & No & No \\
\hline Adj. R2 & 0.84 & 0.83 & 0.84 & 0.83 & 0.83 \\
\hline
\end{tabular}

Notes: OLS estimation. Dependent variable: Percentage share of yes-votes in electorate.

Standard errors are reported in parentheses. ${ }^{* *}, *$ and \# denote significant at the 1,5 and 10 percent level, respectively. The number of observations is 1,197 . 
Figure 1: Map of Berlin

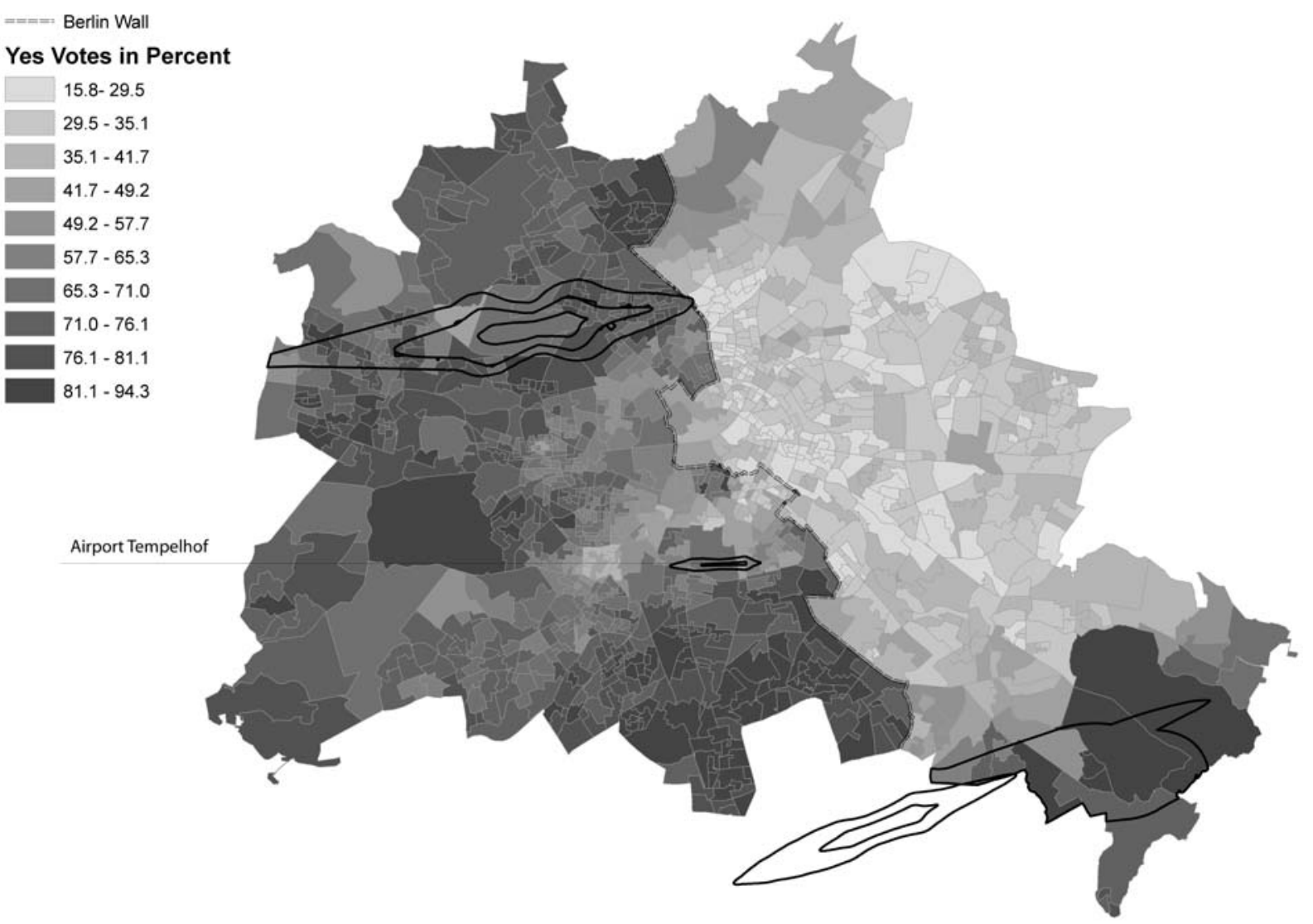

Notes: The map shows the areas of polling places, the noise corridors of Berlin airports, and a rough classification of referendum results. Groups have been defined according to the "natural break method" by Jenks (1977); this method identifies breaks in the ordered distribution of values that minimize the within-class sum of squared differences. 
Figure 2: Referendum results by mode of vote taking

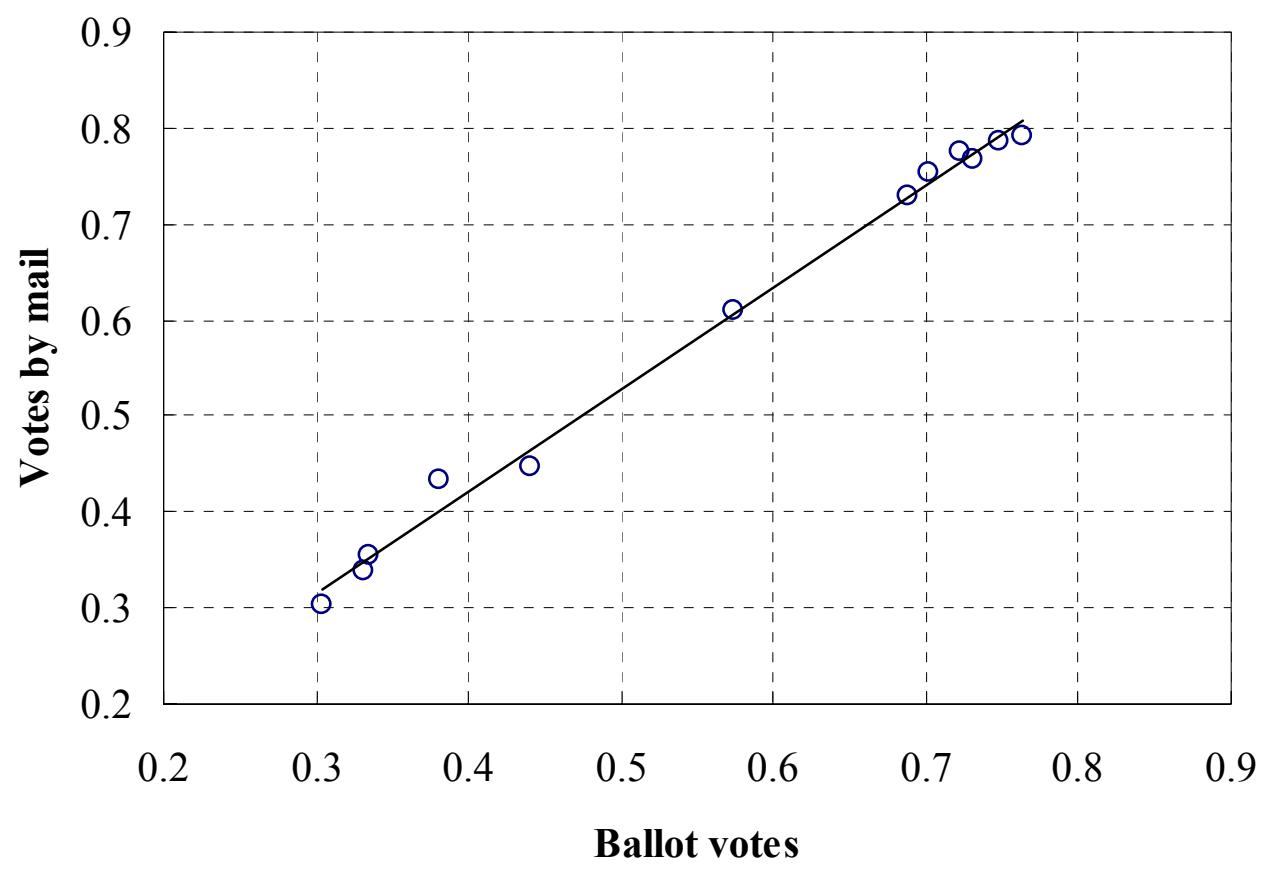

Notes: The figure shows the percentage of yes-votes by mode of vote taking for the 12 Berlin city districts. 
Appendix: Definitions and Descriptive Statistics

\begin{tabular}{|c|c|c|c|c|c|}
\hline & & Mean & $\begin{array}{l}\text { Std. } \\
\text { Dev. }\end{array}$ & Min. & Max. \\
\hline $\begin{array}{l}\text { Percentage share } \\
\text { of yes-votes in } \\
\text { electorate }\end{array}$ & $\begin{array}{l}\text { Number of yes votes as a } \\
\text { fraction of all eligible voters }\end{array}$ & 16.5 & 9.03 & 2.88 & 44.94 \\
\hline $\begin{array}{l}\text { Percentage share } \\
\text { of yes-votes in } \\
\text { total votes }\end{array}$ & $\begin{array}{l}\text { Number of yes votes as a } \\
\text { fraction of all votes cast }\end{array}$ & 56.82 & 20.45 & 15.84 & 94.33 \\
\hline $\begin{array}{l}\text { Percentage rate of } \\
\text { voter } \\
\text { participation }\end{array}$ & $\begin{array}{l}\text { Number of voters as a } \\
\text { fraction of all eligible voters }\end{array}$ & 27.44 & 7.78 & 7.26 & 48.42 \\
\hline $\begin{array}{l}\text { Majority of votes } \\
=\text { yes \& yes-votes } \\
\geq 25 \% \text { of } \\
\text { electorate }\end{array}$ & $\begin{array}{l}=1 \text { if number of yes votes is } \\
>50 \% \text { of all votes and } \geq 25 \% \\
\text { of all eligible voters, }=0 \\
\text { otherwise }\end{array}$ & 0.21 & 0.41 & 0 & 1 \\
\hline $\begin{array}{l}\text { Majority of votes } \\
=\text { yes }\end{array}$ & $\begin{array}{l}=1 \text { if number of yes votes is } \\
>50 \% \text { of all votes, }=0 \\
\text { otherwise }\end{array}$ & $0-59$ & 0.49 & 0 & 1 \\
\hline $\begin{array}{l}\text { Yes-votes } \geq 25 \% \\
\text { of electorate }\end{array}$ & $\begin{array}{l}=1 \text { if number of yes votes is } \\
\geq 25 \% \text { of all eligible voters, }= \\
0 \text { otherwise }\end{array}$ & 0.21 & 0.41 & 0 & 1 \\
\hline $\begin{array}{l}\text { Noise Protection } \\
\text { Zone }\end{array}$ & $\begin{array}{l}=1 \text { if district located in noise } \\
\text { protection zone of THF } \\
\text { airport, }=0 \text { otherwise }\end{array}$ & 0.009 & 0.095 & 0 & 1 \\
\hline $\begin{array}{l}\text { Noise }(<500 \mathrm{~m} \\
\text { from THF })\end{array}$ & $\begin{array}{l}=\text { average noise level in } \\
\mathrm{dB}(\mathrm{A}) \text { if district located less } \\
\text { than } 500 \text { meters from THF } \\
\text { airport, }=0 \text { otherwise }\end{array}$ & 0.09 & 2.11 & 0 & 51.89 \\
\hline 0-2km from THF & $\begin{array}{l}=1 \text { if district located less } \\
\text { than } 2 \text { kilometers from THF } \\
\text { airport, }=0 \text { otherwise }\end{array}$ & 0.016 & 0.125 & 0 & 1 \\
\hline 2-4km from THF & $\begin{array}{l}=1 \text { if district located more } \\
\text { than } 2 \text { but less than } 4 \\
\text { kilometers from THF airport, } \\
=0 \text { otherwise }\end{array}$ & 0.086 & 0.281 & 0 & 1 \\
\hline 4-6km from THF & $\begin{array}{l}=1 \text { if district located more } \\
\text { than } 5 \text { but less than } 6 \\
\text { kilometers from THF airport, } \\
=0 \text { otherwise }\end{array}$ & 0.125 & 0.331 & 0 & 1 \\
\hline $\begin{array}{l}\text { Distance from } \\
\text { THF }\end{array}$ & $\begin{array}{l}\text { Distance from Tempelhof } \\
\text { airport in meters }\end{array}$ & 9728 & 4630 & 749 & 22272 \\
\hline Noise & Average noise level in $\mathrm{dB}(\mathrm{A})$ & 57.3 & 5.4 & 30.9 & 72.6 \\
\hline East & $\begin{array}{l}=1 \text { if district located in } \\
\text { former East Berlin, }=0 \\
\text { otherwise }\end{array}$ & 0.423 & 0.494 & 0 & 1 \\
\hline Electorate & Number of eligible voters & 2033 & 854 & 243 & 5451 \\
\hline Area & Surface area in square meters & 740231 & $\begin{array}{l}157863 \\
2\end{array}$ & 31566 & 24718399 \\
\hline
\end{tabular}




\begin{tabular}{|l|l|l|l|l|l|}
\hline SPD & $\begin{array}{l}\text { Share of votes for SPD } \\
\text { (social democrats) in 2006 } \\
\text { election }\end{array}$ & 0.319 & 0.043 & 0.163 & 0.484 \\
\hline CDU & $\begin{array}{l}\text { Share of votes for CDU } \\
\text { (christian democrats) in 2006 } \\
\text { election }\end{array}$ & 0.202 & 0.101 & 0.027 & 0.481 \\
\hline Linke & $\begin{array}{l}\text { Share of votes for Linke } \\
\text { former communists) in 2006 } \\
\text { election }\end{array}$ & 0.128 & 0.118 & 0.007 & 0.482 \\
\hline Grüne & $\begin{array}{l}\text { Share of votes for FDP } \\
\text { (liberals) in 2006 election }\end{array}$ & 0.073 & 0.035 & 0.013 & 0.238 \\
\hline $\begin{array}{l}\text { Share of votes for Grüne } \\
\text { (environmentalists) in 2006 } \\
\text { election }\end{array}$ & 0.131 & 0.090 & 0.009 & 0.475 \\
\hline
\end{tabular}

Notes: Number of observations $=1197$. 


\section{CESifo Working Paper Series}

for full list see www.cesifo-group.org/wp

(address: Poschingerstr. 5, 81679 Munich, Germany, office@cesifo.de)

2669 Aleksandra Riedl and Silvia Rocha-Akis, Testing the Tax Competition Theory: How Elastic are National Tax Bases in OECD Countries?, June 2009

2670 Dominique Demougin and Carsten Helm, Incentive Contracts and Efficient Unemployment Benefits, June 2009

2671 Guglielmo Maria Caporale and Luis A. Gil-Alana, Long Memory in US Real Output per Capita, June 2009

2672 Jim Malley and Ulrich Woitek, Productivity Shocks and Aggregate Cycles in an Estimated Endogenous Growth Model, June 2009

2673 Vivek Ghosal, Business Strategy and Firm Reorganization under Changing Market Conditions, June 2009

2674 Francesco Menoncin and Paolo M. Panteghini, Retrospective Capital Gains Taxation in the Real World, June 2009

2675 Thomas Hemmelgarn and Gaëtan Nicodème, Tax Co-ordination in Europe: Assessing the First Years of the EU-Savings Taxation Directive, June 2009

2676 Oliver Himmler, The Effects of School Competition on Academic Achievement and Grading Standards, June 2009

2677 Rolf Golombek and Michael Hoel, International Cooperation on Climate-Friendly Technologies, June 2009

2678 Martin Cave and Matthew Corkery, Regulation and Barriers to Trade in Telecommunications Services in the European Union, June 2009

2679 Costas Arkolakis, A Unified Theory of Firm Selection and Growth, June 2009

2680 Michelle R. Garfinkel, Stergios Skaperdas and Constantinos Syropoulos, International Trade and Transnational Insecurity: How Comparative Advantage and Power are Jointly Determined, June 2009

2681 Marcelo Resende, Capital Structure and Regulation in U.S. Local Telephony: An Exploratory Econometric Study; June 2009

2682 Marc Gronwald and Janina Ketterer, Evaluating Emission Trading as a Policy Tool Evidence from Conditional Jump Models, June 2009

2683 Stephan O. Hornig, Horst Rottmann and Rüdiger Wapler, Information Asymmetry, Education Signals and the Case of Ethnic and Native Germans, June 2009 
2684 Benoit Dostie and Rajshri Jayaraman, The Effect of Adversity on Process Innovations and Managerial Incentives, June 2009

2685 Peter Egger, Christian Keuschnigg and Hannes Winner, Incorporation and Taxation: Theory and Firm-level Evidence, June 2009

2686 Chrysovalantou Milliou and Emmanuel Petrakis, Timing of Technology Adoption and Product Market Competition, June 2009

2687 Hans Degryse, Frank de Jong and Jérémie Lefebvre, An Empirical Analysis of Legal Insider Trading in the Netherlands, June 2009

2688 Subhasish M. Chowdhury, Dan Kovenock and Roman M. Sheremeta, An Experimental Investigation of Colonel Blotto Games, June 2009

2689 Alexander Chudik, M. Hashem Pesaran and Elisa Tosetti, Weak and Strong Cross Section Dependence and Estimation of Large Panels, June 2009

2690 Mohamed El Hedi Arouri and Christophe Rault, On the Influence of Oil Prices on Stock Markets: Evidence from Panel Analysis in GCC Countries, June 2009

2691 Lars P. Feld and Christoph A. Schaltegger, Political Stability and Fiscal Policy - Time Series Evidence for the Swiss Federal Level since 1849, June 2009

2692 Michael Funke and Marc Gronwald, A Convex Hull Approach to Counterfactual Analysis of Trade Openness and Growth, June 2009

2693 Patricia Funk and Christina Gathmann, Does Direct Democracy Reduce the Size of Government? New Evidence from Historical Data, 1890-2000, June 2009

2694 Kirsten Wandschneider and Nikolaus Wolf, Shooting on a Moving Target: Explaining European Bank Rates during the Interwar Period, June 2009

2695 J. Atsu Amegashie, Third-Party Intervention in Conflicts and the Indirect Samaritan's Dilemma, June 2009

2696 Enrico Spolaore and Romain Wacziarg, War and Relatedness, June 2009

2697 Steven Brakman, Charles van Marrewijk and Arjen van Witteloostuijn, Market Liberalization in the European Natural Gas Market - the Importance of Capacity Constraints and Efficiency Differences, July 2009

2698 Huifang Tian, John Whalley and Yuezhou Cai, Trade Sanctions, Financial Transfers and BRIC's Participation in Global Climate Change Negotiations, July 2009

2699 Axel Dreher and Justina A. V. Fischer, Government Decentralization as a Disincentive for Transnational Terror? An Empirical Analysis, July 2009

2700 Balázs Égert, Tomasz Koźluk and Douglas Sutherland, Infrastructure and Growth: Empirical Evidence, July 2009 
2701 Felix Bierbrauer, Optimal Income Taxation and Public Goods Provision in a Large Economy with Aggregate Uncertainty, July 2009

2702 Marc Gronwald, Investigating the U.S. Oil-Macroeconomy Nexus using Rolling Impulse Responses, July 2009

2703 Ali Bayar and Bram Smeets, Government Deficits in the European Union: An Analysis of Entry and Exit Dynamics, July 2009

2704 Stergios Skaperdas, The Costs of Organized Violence: A Review of the Evidence, July 2009

2705 António Afonso and Christophe Rault, Spend-and-tax: A Panel Data Investigation for the EU, July 2009

2706 Bruno S. Frey, Punishment - and beyond, July 2009

2707 Michael Melvin and Mark P. Taylor, The Crisis in the Foreign Exchange Market, July 2009

2708 Firouz Gahvari, Friedman Rule in a Model with Endogenous Growth and Cash-inadvance Constraint, July 2009

2709 Jon H. Fiva and Gisle James Natvik, Do Re-election Probabilities Influence Public Investment?, July 2009

2710 Jarko Fidrmuc and Iikka Korhonen, The Impact of the Global Financial Crisis on Business Cycles in Asian Emerging Economies, July 2009

2711 J. Atsu Amegashie, Incomplete Property Rights and Overinvestment, July 2009

2712 Frank R. Lichtenberg, Response to Baker and Fugh-Berman's Critique of my Paper, "Why has Longevity Increased more in some States than in others?", July 2009

2713 Hans Jarle Kind, Tore Nilssen and Lars Sørgard, Business Models for Media Firms: Does Competition Matter for how they Raise Revenue?, July 2009

2714 Beatrix Brügger, Rafael Lalive and Josef Zweimüller, Does Culture Affect Unemployment? Evidence from the Röstigraben, July 2009

2715 Oliver Falck, Michael Fritsch and Stephan Heblich, Bohemians, Human Capital, and Regional Economic Growth, July 2009

2716 Wladimir Raymond, Pierre Mohnen, Franz Palm and Sybrand Schim van der Loeff, Innovative Sales, R\&D and Total Innovation Expenditures: Panel Evidence on their Dynamics, July 2009

2717 Ben J. Heijdra and Jochen O. Mierau, Annuity Market Imperfection, Retirement and Economic Growth, July 2009 
2718 Kai Carstensen, Oliver Hülsewig and Timo Wollmershäuser, Price Dispersion in the Euro Area: The Case of a Symmetric Oil Price Shock, July 2009

2719 Katri Kosonen and Gaëtan Nicodème, The Role of Fiscal Instruments in Environmental Policy, July 2009

2720 Guglielmo Maria Caporale, Luca Onorante and Paolo Paesani, Inflation and Inflation Uncertainty in the Euro Area, July 2009

2721 Thushyanthan Baskaran and Lars P. Feld, Fiscal Decentralization and Economic Growth in OECD Countries: Is there a Relationship?, July 2009

2722 Nadia Fiorino and Roberto Ricciuti, Interest Groups and Government Spending in Italy, 1876-1913, July 2009

2723 Andreas Wagener, Tax Competition, Relative Performance and Policy Imitation, July 2009

2724 Hans Fehr and Fabian Kindermann, Pension Funding and Individual Accounts in Economies with Life-cyclers and Myopes, July 2009

2725 Ernesto Reuben and Arno Riedl, Enforcement of Contribution Norms in Public Good Games with Heterogeneous Populations, July 2009

2726 Kurt Schmidheiny and Marius Brülhart, On the Equivalence of Location Choice Models: Conditional Logit, Nested Logit and Poisson, July 2009

2727 Bruno S. Frey, A Multiplicity of Approaches to Institutional Analysis. Applications to the Government and the Arts, July 2009

2728 Giovanni Villani, A Strategic R\&D Investment with Flexible Development Time in Real Option Game Analysis, July 2009

2729 Luca Di Corato and Michele Moretto, Investing in Biogas: Timing, Technological Choice and the Value of Flexibility from Inputs Mix, July 2009

2730 Gilad D. Aharonovitz, Nathan Skuza and Faysal Fahs, Can Integrity Replace Institutions? Theory and Evidence, July 2009

2731 Michele Moretto and Sergio Vergalli, Managing Migration through Conflicting Policies: an Option-theory Perspective, July 2009

2732 Volker Nitsch, Fly or Cry: Is Airport Noise Costly?, July 2009 